\title{
De gamle er eldst - eller bare eldre?
}

\author{
Å bli gammel er et naturlig mål for mange av oss, og en stadig voksende del av befolkningen er å anse som \\ eldre. Hvordan brukes egentlig disse begrepene?
}

De eldste blant pasientene våre utgjør en så kompleks og utfordrende gruppe at geriatri omtales som et fag bare for de tøffeste i klassen (1). Adjektivet gammel (positiv) bøyes eldre (komparativ) og eldst (superlativ). I manges ører vil nok allikevel en gammel dame oppfattes som eldre enn en eldre dame. Mens eldst kan være en hedersbetegnelse i visse sammenhenger, oppfattes gammel gjerne som mer negativt. Begrepet gammel og god brukes for eksempel om vin og er et hederlig unntak. Allikevel foretrekker eldre gjerne eldre eller modne fremfor gamle $(2,3)$. Eldre er verken mer eller mindre og passer bra for nordmenn, som gjerne velger den moderate middelvei for å unngå å tråkke andre på tærne.

Uttrykket de gamle er eldst brukes hyppig når eldre klarer å beseire yngre konkurrenter, som da Ole Einar Bjørndalen vant $\mathrm{OL}$-gull i skiskyting sist vinter. $\mathrm{Og}$ ifølge Verdens helseorganisasjons definisjoner er de gamle eldst: Mens eldre er definert som mennesker mellom 60-74 år, er mennesker $\geq 75$ år definert som gamle (4). I medisinsk faglitteratur brukes disse begrepene om hverandre. I engelskspråklig litteratur brukes oftest older, men også old og elderly, for å beskrive populasjoner av eldre (5-7). På norsk brukes oftest eldre, også om mennesker $\geq 75$ år. Eksempler på dette finner vi i Delirium hos eldre pasienter (8), Legemidler og eldre (9) og på forsiden av Tidsskriftet nr. 18/2014: Eldres helse (10).

I de to siste eksemplene står eldre på egne bein uten substantiv. Dette kalles substantivering og er et eksempel på at adjektiver kan benyttes som navnord. Både gammel, eldre og eldst brukes også i sammensatte ord: Gammelheim, gammelkaill (trøndersk) og gammelmodig gir hos mange først og fremst negative assossiasjoner, mens eldrebølgen og eldreomsorg er mer nøytrale moteord. Å være eldstemann kan være både en fordel og en ulempe. Gammelheim eller gamlehjem er også eksempler på ord som er blitt negativt ladet og derfor erstattes med andre ord, som bolig for eldre og bo- og rehabiliteringssenter.

Kronologisk alder er, som kjent, «bare et tall». I Birkebeiner-aldringsstudien, for eksempel, oppga tre av fire blant eldre birkebeinere $\geq 65$ år at de følte seg yngre enn andre på samme alder (upubliserte

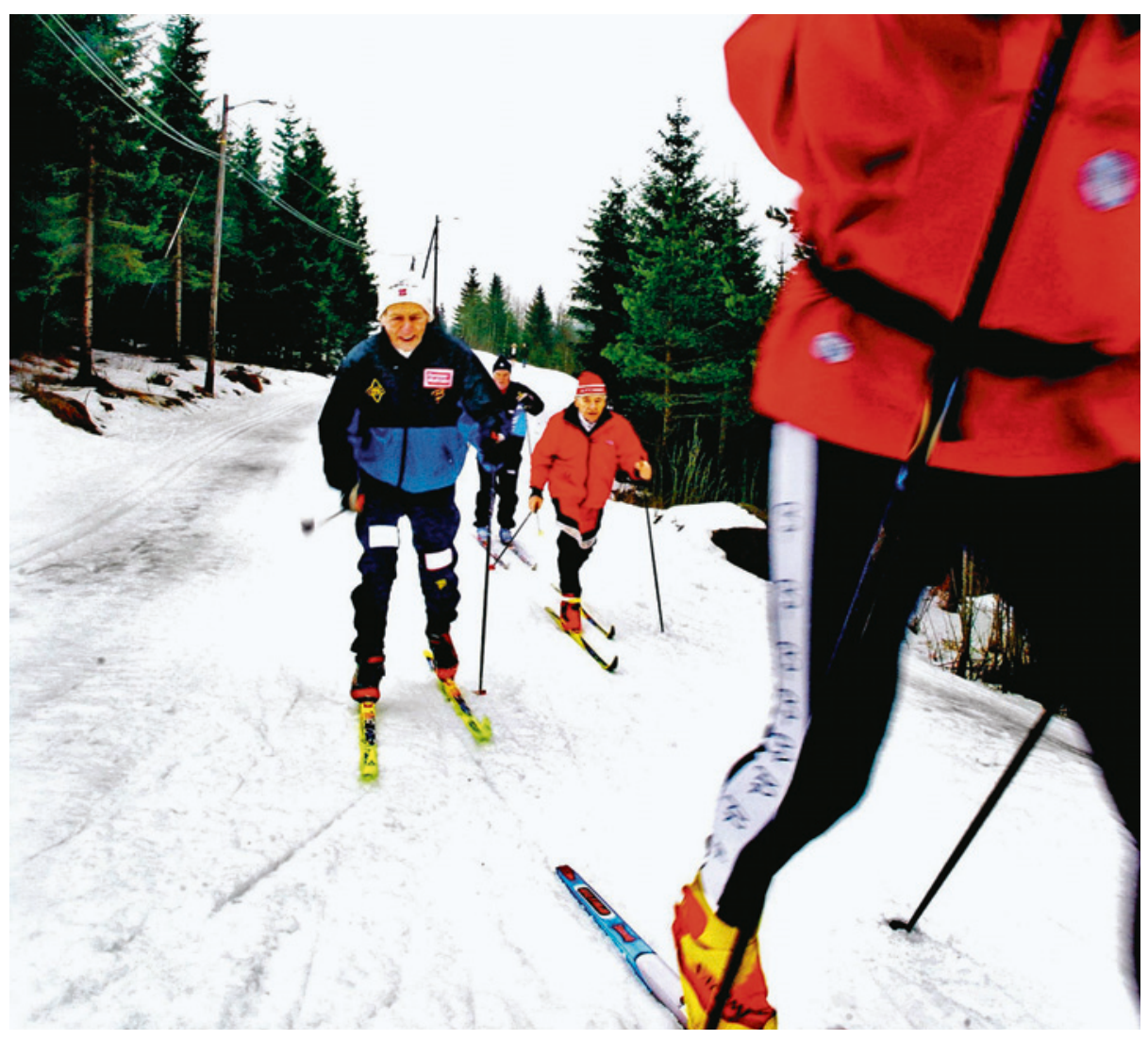

Illustrasjonsfoto: Nina Ruud/NTB scanpix

data). De gamle er eldst, men ikke eldre enn de selv føler seg.

\section{Marius Myrstad}

m-myrsta@online.no

Marius Myrstad (f. 1978) er stipendiat og lege i spesialisering i geriatri og indremedisin ved Diakonhjemmet Sykehus i Oslo.

\section{Litteratur}

1. Gjestad GH. Litt om min mor. www.vg.no/nyheter/ meninger/barn-og-familie/litt-om-min-mor/a/ 23309175/ (12.12.2014).

2. Heiberg AN. Redselen for å bli gammel handler om redsel for ikke å bli regnet med. www.aftenposten.no/meninger/kronikker/ Redselen-for-a-bli-gammel-handler-om-redselfor-ikke-a-bli-regnet-med-7640723.htm (12.12.2014).

3. Lørdagsrevyen 23.8.2014. Lørdagsgjest: Arve Tellefsen. http://tv.nrk.no/serie/dagsrevyen/ NNFA02082314/23-08-2014 (12.12.2014).
4. Store norske leksikon. Alderdom. https://sml.snl.no/alderdom (12.12.2014).

5. Strandberg TE, Kolehmainen L, Vuorio A. Evaluation and treatment of older patients with hypercholesterolemia: a clinical review. JAMA 2014: 312: $1136-44$

6. Taylor WD. Clinical practice. Depression in the elderly. N Engl J Med 2014; 371: 1228-36.

7. Legrand D, Vaes B, Matheï $C$ et al. The prevalence of sarcopenia in very old individuals according to the European consensus definition: insights from the BELFRAIL study. Age Ageing 2013; 42: 727-34

8. Neerland BE, Watne LO, Wyller TB. Delirium hos eldre pasienter. Tidsskr Nor Legeforen 2013; 133: 1596-600.

9. Romskaug R, Wyller TB. Legemidler og eldre. Tidsskr Nor Legeforen 2013; 133: 735.

10. Tidsskrift for Den norske legeforening. Forsidebildet. http://tidsskriftet.no/article/3232820/ (12.12.2014)

Mottatt 15.10. 2014, første revisjon innsendt 12.12 2014, godkjent 28.1. 2015. Redaktør: Marit Skaar Fjellhaug. 